Article

\title{
Dancing with 'The Other': Challenges and Opportunities of Deepening Democracy through Participatory Spaces for Refugees
}

\author{
Maria Charlotte Rast * and Halleh Ghorashi \\ Department of Sociology, Vrije Universiteit Amsterdam, 1081 HV Amsterdam, The Netherlands; E-Mails: m.c.rast@vu.nl \\ (M.C.R.), h.ghorashi@vu.nl (H.G.) \\ * Corresponding author
}

Submitted: 30 November 2017 | Accepted: 28 February 2018 | Published: 29 March 2018

\begin{abstract}
Due to the so-called refugee crisis and the Netherlands' development into a 'participation society', refugee reception there has recently shifted its focus to early and fast participation. In this context, numerous community initiatives have emerged to support refugee reception and integration. Compared to earlier restrictive approaches, refugee reception through active engagement of newcomers in community initiatives seems to promise a more inclusive approach, a deepening of democracy. However, such initiatives have internal and external challenges that might inhibit refugees' active participation and the initiatives' adoption of inclusive approaches. In this qualitative research, we have explored the challenges and opportunities for active participation and inclusion of refugees in community initiatives, considering the context of normalizing exclusive discourses and increasingly neoliberal policies on refugee reception.
\end{abstract}

\section{Keywords}

community initiatives; deep democracy; exclusion; inclusion; power; reflection; refugees

Issue

This article is part of the issue "The Transformative Forces of Migration: Refugees and the Re-Configuration of Migration Societies", edited by Ulrike Hamann and Gökçe Yurdakul (Humboldt University of Berlin, Germany).

(C) 2018 by the authors; licensee Cogitatio (Lisbon, Portugal). This article is licensed under a Creative Commons Attribution 4.0 International License (CC BY).

\section{Introduction}

Dutch policies on refugee reception and integration have undergone two far-reaching shifts in the past decades. The multicultural approach that emerged in the late 1970s became rather restrictive by the end of the 20th century (Vasta, 2007). Challenges regarding immigration and cultural diversity incited anti-immigrant sentiments and led to a re-emergence of right-wing parties. Pluralist or multicultural approaches to immigrant incorporation were said to have failed, resulting in the emergence of assimilationist discourses and policies (Vasta, 2007). In this context, starting in 1988, refugee reception in the Netherlands became strictly institutionalized and characterized by seclusion from society, long waiting periods, and dependence on host society support (Engbersen et al., 2015; Geuijen, 2003; Ghorashi, 2005).
In recent years, however, the discourse on and approach to refugee reception have shifted. Several institutions and scholars have criticized the established approach's negative effects on the (economic) participation and societal inclusion of refugees (e.g., Adviescommissie voor Vreemdelingenzaken, 2013; Engbersen et al., 2015; ten Holder, 2012). Concomitantly, the Netherlands has increasingly developed into a so-called participation society in which governments appeal to citizens' civic responsibilities and local community engagement (Raad voor Maatschappelijke Ontwikkeling [RMO], 2013). Accordingly, refugee reception has shifted: first, to refugees being responsible for their own integration, which was given formal legal force with the 2013 law on integration; and second, to early and fast refugee participation through specialized programs that have been initiated by Dutch municipalities since the influx of asylum seekers 
in 2015 (Dagevos \& Odé, 2016). Moreover, since the socalled refugee crisis in 2015, numerous community initiatives have emerged in the Netherlands that now play an important role in refugee reception and integration (Start, 2016).

Community initiatives offer opportunities, such as education courses, that help refugees develop skills. In addition, the literature on citizen engagement (e.g., Ghorashi, 2014a) suggests that refugees' active participation as volunteers in community initiatives might also contribute to a deepening of democracy. However, critical diversity scholars show that minority participation does not necessarily promote inclusion, even if the intention is to include (e.g. van der Raad, 2013). Since the approach to refugee reception has only recently shifted, no empirical research has yet explored these assumptions. We claim that shedding more light on such challenges and opportunities of refugees' active participation in community initiatives is crucial and urgent. If the aim of 'activating' refugees fails, the neoliberal Dutch discourse that stresses refugees' responsibility for their own integration process could easily result in practices of 'blaming the victim' for unsuccessful inclusion (Ponzoni, Ghorashi, \& van der Raad, 2017). Our research adds nuance to this discussion by showing that, while responsibilities might shift to individuals and local communities, actors are still very much dependent on and influenced by societal structures and discourses that can undermine community initiatives' aims. Thus, this article also contributes to the literature on power issues and inclusion around cultural diversity in 'created spaces' (Gaventa, 2006). After a theoretical discussion of power issues around participation and inclusion, we will briefly elaborate on our methodological choices. We will then discuss the findings from our four-month qualitative field research in a local community initiative for refugees in Amsterdam East to answer the following question:

What are the challenges and opportunities for active participation and inclusion of refugees in community initiatives, considering the context of normalizing exclusive discourses and increasingly neoliberal policies on refugee reception?

\section{Theoretical Framework}

\subsection{Opportunities for Created Spaces}

The recent developments in refugee reception of individual responsibility and community engagement are very much in line with the Dutch trend towards a participation society. Notwithstanding critique of the participation society as a means to conceal governmental budget cuts (e.g., RMO, 2013), community engagement is seen by many scholars as a remedy to democratic deficits. Citizen participation in the democratic system entails the redistribution of power, though the extent of empowerment depends on the type of participation (Arnstein, 1969). Gaventa (2006) distinguishes between three spaces in which citizens can become active and potentially affect their environment. 'Closed spaces' are exclusively reserved for a set of representatives-usually elites-to make decisions in. 'Invited spaces' are institutionalized spaces for consulting a broader public. These deliberative spaces have been criticized for their failure to enforce the principle of equal consideration, and for their bias towards the deliberative capacities, interests and norms of discourse of dominant groups (e.g., Bohman, 1996; Holdo, 2015; Young, 2001). Finally, 'created' or 'claimed spaces' are established by less powerful actors from or against power holders outside of institutionalized policy arenas. Such spaces are considered the most empowering form of participation, since they are controlled by citizens (e.g., Arnstein, 1969; Gaventa, 2006; Ghorashi, 2014a). In these spaces, previously excluded actors can engage in the public sphere and shape their environment on the local level, thereby deepening democracy (Cornwall \& Gaventa, 2000; Fung \& Wright, 2003; Ghorashi, 2014a). Accordingly, the emergence of community initiatives for refugees might constitute a turn towards a more inclusive approach to refugee reception: they offer a chance for refugees to take an active part in shaping their integration process for themselves.

\subsection{Challenges of Created Spaces}

There are several challenges that could undermine the potential of community initiatives to facilitate the participation and inclusion of refugees. First, citizen engagement is an intense form of participation in terms of skills, time, energy and resources. Verba, Schlozman and Brady (1995) have found that newly emerging intense forms of participation might even result in stronger inequalities in participation than conventional forms do. Second, created spaces are not necessarily free of power issues just because they take place outside of institutionalized arenas. In the Dutch participation society, community engagement is stimulated by the government. This means the government exerts influence by defining the goals, conditions and expected results for initiatives that want governmental (financial) support (RMO, 2013). Moreover, one needs to question whether active citizenship can be equated with autonomy at all. Cruikshank (1999) shows how participatory and democratic schemes 'operate according to a political rationality for governing people in ways that promote their autonomy, selfsufficiency, and political engagement' (p. 4). While this does not necessarily deny individuals all autonomy, it still means that democratic citizens 'are both the effects and the instruments of liberal governance' (Cruikshank, 1999, p. 4). Finally, even if equal access, equal participation and independence from governmental influences were ensured, a truly inclusive approach might still be endangered by power issues between participants within the initiative. According to Young (2001), the dominant discourse is hegemonic, meaning that 'most of the people in the society think about their social relations in these 
terms' (p. 685). Consequently, images of refugees as a threat to national security and culture and images of refugees as weak victims can both feed the self-other gap between locals and refugees (Ghorashi, 2005; Ponzoni et al., 2017; Reinhard, 2016). An inclusive approach to refugee reception might therefore be undermined at an interpersonal level.

\subsection{How to Be Inclusive of Diversity?}

When studying power around created spaces, scholars usually focus on relationships between stakeholders in the field (e.g., Gaventa, 2006), giving limited attention to power within initiatives. Adding cultural or ethnic diversity to the equation, however, brings additional internal challenges. As mentioned in Section 2.1, Young (2001) claims that, in a system with longstanding and multiple structural inequalities, people are at least partly influenced by unjust power relations, which can result in a reproduction of exclusive structures. Ongoing discussions in critical diversity studies on power within organizations (e.g., Zanoni \& Janssens, 2007) provide us with a valuable framework for studying power at the micro- and mesolevel, in this case within community initiatives. Critical theorists claim that, even when the intention is to include minority employees, there is always a danger of assimilating or marginalizing them (Ghorashi \& Sabelis, 2013; van der Raad, 2013). Ely and Thomas (2001), for example, distinguish between the 'discrimination-and-fairness' perspective, which addresses discrimination by assimilating difference into sameness, and the 'access-and-legitimacy' perspective, which sees diversity mostly as a way to get access to a more diverse clientele. Even though these approaches might increase the number of minority employees within organizations, they are not truly inclusive of diversity. Inclusion can, according to Thomas and Ely (1996), be achieved through an 'integration-and-learning' perspective, which requires organizations to incorporate minority employees' perspectives and redefine 'markets, products, strategies, missions, business practices and even cultures' (p. 85). This paradigm therefore allows space for minority employees to make a difference (Janssens \& Steyaert, 2001). Thus, for community initiatives to adopt an inclusive approach to refugees' participation, they need to be open to changing the initiative's mind-set and challenging its institutional relations according to newcomers' perspectives.

\subsection{Reflective Capacity}

Critical diversity scholars claim that the development of such an inclusive space requires reflective capacity to counteract taken-for-granted forms of exclusion (e.g., Ghorashi \& Ponzoni, 2014; Zanoni \& Janssens, 2007). However, the question of whether individuals can adopt this reflective capacity is quite controversial. In the Foucauldian perspective, power works through normaliz- ing discourses and resides in every perception, judgment and act, thereby unconsciously subjecting all actors to 'disciplinary power' (Hardy \& Leiba-O'Sullivan, 1998). Emancipation through knowledge is therefore nearly impossible (Cronin, 1996). However, 'while the power of discursive practices affects everyone, because there are competing discourses socialization into any one discourse is never complete, and resistance to specific discursive regimes is thus possible' (Foucault in Clarke, Brown, \& Hailey, 2009, p. 325). Accordingly, competing discourses on refugees might be a source for resistance, but they can be a chance for inclusion only if one of the discourses is inclusive.

Similar to Foucault, Bourdieu claims that knowledge is internalized and functions below the level of consciousness as part of the repertoire of a person's habitus (Jenkins, 1992). Because of their bodily adherence to the taken-for-granted representation of the social world, social agents unconsciously reproduce relations of domination (Bourdieu, 1977). In his later work, Bourdieu (1999) acknowledges that the confrontation of one's habitus with a new field can lead to self-questioning, or even an awakening of consciousness. Constant negotiation of the habitus with itself might eventually lead to a modified habitus and a 'feel for the game' (Bourdieu, 1999). A created space as a specific field might therefore inspire self-questioning in people whose habitus is in tension with this field. Nonetheless, Sayer (2005) argues that Bourdieu neglects the role of everyday reflexivity through which individuals sometimes manage to resist constraints by deliberating on their situation and working on developing their dispositions, thereby changing their habitus. Moreover, as argued in Section 2.3, the problem with reproducing exclusion is not only about the reflections of minorities whose habitus are in tension with the field; it is also about dominant groups that need to develop reflective capacity. Instead of minorities 'playing the game' (Greener, 2002), the game needs to change.

A concept that acknowledges individuals' capacities to manoeuver through everyday reflective action is referred to by critical diversity scholars as 'microemancipation' (Zanoni \& Janssens, 2007). According to Ghorashi (2014a), taken-for-granted forms of exclusion that work through normalizing discursive processes can only be counteracted by an alternative that works in the same subtle and 'micro' manner. Micro-emancipation can be achieved through 'partial, temporal movements breaking away from diverse forms of oppression, rather than successive moves towards a predetermined state of liberation' (Alvesson \& Willmott, 1992, p. 447). Ghorashi (2014a) also shows how space for such reflective actions can be created in interpersonal encounters. She suggests that delayed 'interspaces' are needed, where people take time to temporarily suspend their own takenfor-granted positions and truly listen to 'the other'. In a balancing act between sameness and difference, people should try to approach the other from his or her own position. By engaging in this dance of 'giving away' their po- 
sition and thereby 'giving way', people might unsettle established positions and relate to the other in new ways (Ghorashi, 2014a). Finally, Ghorashi and Ponzoni (2014) argue that, to stimulate alternative discourses beyond interpersonal levels, 'safe spaces' need to be created on a collective level, wherein individuals can position themselves through difference, for example through storytelling, literature or music (see also Hill Collins, 1991; Ghorashi, 2014b).

The section above suggests that, to establish a truly inclusive space, community initiatives have to stimulate reflection. Alternative discourses and confronting people's habitus with new environments can be sources for reflection. However, it is individuals' daily reflections and the establishing of interpersonal interspaces and collective safe spaces that are required for community initiatives to open their mind-sets, challenge their institutional relations and develop inclusive approaches to refugee reception.

\section{Methodology}

We collected data during four months of fieldwork within a community initiative in Amsterdam East that emerged in September 2016. We chose this initiative because it is a self-organized community center that wants to give newcomers and locals the opportunity to jointly develop its program. The initiative collaborates with multiple stakeholders, including the municipality of Amsterdam and the district of Amsterdam East. It was therefore well suited for exploring the challenges and opportunities of refugee participation and inclusion in community initiatives, while considering influences from both inside and outside the initiative.

Our research employed a constructivist paradigm, which assumes there is 'no single shared social reality, only a series of alternative social constructions' (Ritchie, Lewis, McNaughton Nicholls, \& Ormston, 2014, p. 16). Therefore, we chose an interpretivist epistemological approach, which allows the exploration of meanings and interpretations of individuals (Ritchie et al., 2014). The exploratory nature of this study required an inductive research process (Saunders, Lewis, \& Thornhill, 2009). Moreover, 'triangulation of sources' through multimethod data collection helped us gain a nuanced and multidimensional picture of our respondents' reality and improved our data validity (Ritchie et al., 2014).

We conducted 120 hours of participant observations during daily activities, public events and an evening of dialogue on equality. By focusing on situations with features that enabled 'detailed exploration and understanding of the central themes and questions' (Ritchie et al., 2014, p. 113), we applied a purposive sampling technique. Observations were conducted as 'participant as observer' (Saunders et al., 2009), meaning that researchers actively participated in the situations they observed and other participants were aware of the research activities. To further examine relevant themes and individual interpretations, we conducted informal conversations and 11 in-depth interviews, applying purposive sampling: we approached eight people with a refugee background (six volunteers and two not actively involved) and three local volunteers (one volunteer, one core team member and the initiator). Since mostly male Syrian and Iranian recent refugees were volunteering in the initiative at that time, we focused mainly on this group. Challenges and opportunities for female refugees or refugees with different backgrounds should therefore be studied in future research. Interviews took between 55 and 105 minutes. Topics discussed were the respondent's background; reasons for joining the initiative; reasons for (not) actively participating; benefits of active participation; experiences with and perceptions on active participation; relationships within the initiative; tensions and problem-solving strategies; and future plans. Nine interviews were audiotaped and transcribed verbatim (Saunders et al., 2009); two interviewees preferred not to be recorded but allowed us to take minutes. Five interviews were conducted in English, six in Dutch. The respondents' characteristics can be found in Table 1.

Table 1. Characteristics of respondents.

\begin{tabular}{llllll}
\hline No. & Country of origin & Sex & Background information & $\begin{array}{l}\text { Language } \\
\text { interview }\end{array}$ & $\begin{array}{l}\text { Function within } \\
\text { initiative }\end{array}$ \\
\hline 1 & Syria & Male & Recent refugee & English & Volunteer \\
$2^{*}$ & Syria & Male & Recent refugee & English & $\begin{array}{l}\text { Volunteer } \\
\text { English }\end{array}$ \\
3 & Iran & Male & Recent refugee & English & Volunteer \\
4 & Syria & Male & Recent refugee & Dutch & Volunteer \\
5 & Syria & Male & Recent refugee & Dutch & Not active as volunteer \\
6 & Syria & Male & Recent refugee & English & Not active as volunteer \\
$7^{*}$ & Syria & Male & Recent refugee & Dutch & Volunteer \\
8 & Algeria & Male & Former refugee, naturalized Dutch & Dutch & Core team member \\
9 & Italy/Netherlands & Female & Dutch-Italian & Dutch & Volunteer \\
10 & Italy & Female & Former immigrant, naturalized Dutch & Dutch & Initiator \\
11 & Netherlands & Female & Dutch & &
\end{tabular}

Note: *Only summary available due to refusal to make recording. 
Finally, we organized a meeting with five members of the initiative's core team and two volunteers (one local, one newcomer). This meeting served three purposes, namely, 'respondent validation' (Ritchie et al., 2014), verification of 'data saturation' (Saunders et al., 2009) and reflecting on research findings and solutions. Close engagement with the community helped us build relationships and trust with respondents, which was crucial considering this study's sensitive content. Moreover, we did not want to simply 'withdraw data' from the community; we also wanted to 'give back' to it by stimulating the community's reflexive capacity, thereby embracing the responsibility that Wright Mills (1959) had in mind for sociologists.

All data was analyzed with Atlas.ti software. We first took a 'topic-driven approach' (Ritchie et al., 2014) by developing an a priori hierarchical (two-level) code list inspired by sensitizing concepts and interview topics. We then took a 'data-driven approach' (Ritchie et al., 2014). Instead of simply 'indexing' sections, we added a third level of descriptive codes. This mixture of topic- and data-driven approaches allowed us to 'stay grounded in the data', while keeping an eye on our overarching research question (Ritchie et al., 2014). This process revealed several patterns that will be presented in the following section.

\section{Empirical Findings}

Before discussing the challenges and opportunities for participation and inclusion of newcomers in the initiative, we provide some contextual information about the initiative's program. The initiative is rather successful in that around 200 newcomers regularly participate in the program, which is arranged by about 100 volunteers. The program mainly consists of language courses and informal conversation lessons, during which newcomers can practice their language skills in an informal way. Local volunteers teach Dutch and English languages and lead the informal conversation lessons. Additionally, a Syrian newcomer teaches an Arabic class for Dutch people. The initiative also set up sewing and biking lessons for women and a buddy project to help newcomers find jobs. In addition to teaching positions, there are several possibilities for volunteers: every day, a different kitchen team prepares lunch for all course participants and volunteers; the bar is open daily from 10 am until 4 pm; there are several coordination tasks; and individuals can develop their own projects, such as computer lessons, singing lessons, sports activities or theatre projects.

In general, both locals and newcomers value the initiative's work, which is confirmed by the large number of people participating in it. However, recruiting newcomers as regular volunteers remains a challenge. Newcomers, if actively involved at all, mostly fulfil 'supportive tasks', for example behind the bar, in the kitchen, as a janitor, or providing sporadic help during public events. Most structured voluntary positions, such as teaching, managing, coordinating and organizing, are filled by lo- cals. Our research revealed several challenges and opportunities for the active participation of refugees in the initiative. After presenting these, we will show how limited active participation of newcomers also makes it difficult to establish a truly inclusive participatory space within the initiative.

\subsection{Opportunities for Active Participation}

The newcomers we interviewed attributed various benefits to their active participation in the initiative. They all mentioned that it helped them learn the language, develop their social network and make friends. However, active participation in the initiative was part of a clear strategy towards integration for only one newcomer-respondent. He saw it as an opportunity to combine learning the language with receiving a volunteer's allowance and developing his network, thereby slowly becoming part of Dutch society. Other newcomerrespondents also acknowledged these benefits. However, this was not these newcomer-respondents' primary reason for participating. One newcomer tried to spend as much time as possible outside the asylum center. Another discovered that many newcomers did not know how to work with computers and decided to set up a course because of his fascination for computers. Some saw their voluntary engagement as an exchange for the language courses they took. An interesting finding was that feelings of inequality or the negative Dutch discourse on refugees also inspired newcomers to become active. Most newcomers who acted in the theatre project said they joined the project because they wanted to change negative discourses on refugees in society (participant observation, 23 May 2017). Another newcomerrespondent said that, through volunteering, he could give back to the Dutch, which made him feel more equal.

I don't want to hold my hand out like this all the time, to beg...I want to be equal. Equality. I don't have money yet, but I can give volunteer work. When I volunteer, I feel good. I feel a bit more equal to the Dutch. (Interviewee 5, recent male refugee from Syria, volunteer, translated from Dutch)

\subsection{Controversial Values and Benefits of Active Participation}

Despite the abovementioned benefits, our research revealed that active participation within the initiative was not necessarily seen by newcomers as a valuable and imperative opportunity to work towards integration. This was in part because the context of volunteer work in the Netherlands differed from newcomer-respondents' experiences in their home countries; prevalence and commitment seemed much higher in the Netherlands.

We have some people that want to protect the environment from trash.... Here it's very different. Here 
I see 66-year-old people that come and volunteer. I didn't know. I heard, but I didn't understand how it was exactly. (Interviewee 3 , recent male refugee from Iran, volunteer)

Given the unpaid character of volunteer work, many newcomers perceived the status, value and benefits of volunteering as quite limited.

The experience is not the same. Because in paid work, you have to do too many things that you don't do in volunteer work. A company will push you more to do things. In volunteer work, they cannot push you. That's why you can learn more [in paid work]. (Interviewee 1, recent male refugee from Syria, volunteer)

All newcomer-respondents stressed that they wanted to start their new lives as soon as possible. For them, this meant reuniting with their families, receiving private housing, (re)gaining diplomas and finding paid work in their fields. Seeing the low status and limited benefits they attributed to volunteer work, many newcomerrespondents doubted active engagement in the community would increase their employability. This also had to do with the lack of matches between newcomers' backgrounds and volunteer opportunities.

People should not look for the benefits. Because, for volunteer work, they will not sign a contract. It will not help your CV if you help with painting or moving stuff or anything. Or teaching Arabic, but I study IT. What will it help? (Interviewee 4, recent male refugee from Syria, volunteer)

Active engagement in the initiative, therefore, was not very high on most newcomer-respondents' lists of priorities. Some said they might want to actively participate if the path to paid work was more clear. But in the end, many newcomer-respondents prioritized taking courses or internships in official institutions or firms instead of volunteering in the community initiative.

Because of the language course, I'm very busy and have only a little time to come here to volunteer. Because I first have to focus on Dutch. It's very important. And it's compulsory. If I want to study at the university, I have to reach a certain level. (Interviewee 6, recent male refugee from Syria, course participant, not active as volunteer, translated from Dutch)

\subsection{Challenges around Matching Competences with Opportunities}

Since many volunteer opportunities within the initiative did not match newcomers' backgrounds, the available positions seemed irrelevant for newcomers' professional future. Relevant positions, however, were scarce and required well-developed skills that many newcomers did not possess yet (e.g., language skills, local knowledge, specific ways of working).

You don't really need to have specific skills, but language is a big problem. Helping in the office...well, for that you really need to have a lot of skills. (Interviewee 10 , female, former immigrant from Italy, naturalized Dutch, volunteer, translated from Dutch)

Matching competences with opportunities could be further inhibited by a lack of communication or miscommunication. Many newcomers did not know whether or which volunteer positions were available, while local volunteers and the core team did not know the backgrounds and competences of all newcomers.

A final and quite striking factor that inhibited matching competences with opportunities and thereby the active participation of newcomers within the initiative was the goal of working together on integration itself. The initiator said that, in their high spirits of wanting to help, locals sometimes take over spaces that could otherwise be filled by newcomers.

If we did not steer, this space would be filled with locals that want to do something for refugees. To the extent that there would be no space for refugees anymore. (Interviewee 11, female, Dutch, initiator, translated from Dutch)

Moreover, one newcomer-respondent explained that, since newcomers were on the receiving end of the initiative's goal of working on integration, they could not take an active part in it.

It's really hard. Syrians here are the end users. The people work for them. So what can Syrians do? It's a boost for integration and for Syrians. So what can Syrians do, other than the simple things like teaching Arabic? (Interviewee 4, recent male refugee from Syria, volunteer)

\subsection{Power Inequalities and Reproduction of Exclusionary Structures}

So far, we have presented the challenges and opportunities for refugees' active participation in the initiative. We now turn to the question of how inclusive these participatory spaces are. Though the initiative aimed to develop a space where newcomers and locals could work together on equal terms, its focus on integration meant that images of locals who possess resources (e.g., language skills, time, networks) and refugees who lack resources (e.g., networks, skills, support) remained. Moreover, stigmatizing interactions within the initiative seemed difficult to prevent, especially during public events. One newcomer-respondent explained how participating in public events has repeatedly exposed him to being humiliated. 
I don't like these things, to meet locals and newcomers. It's nothing, it's just for one hour. These are not equal relations.... felt worse because...they treat me differently. Without any reason...people came just to see me. It's a strange feeling. To answer the same questions for almost two years. It's not good. For anyone. (Interviewee 4, recent male refugee from Syria, volunteer)

What is more, as explained in Section 4.2, newcomers' perceptions and contextual embeddedness about the concept of volunteering differed from that of local volunteers. These differences seemed to go hand in hand with different volunteering styles. A member of the core team explained that newcomers' styles were more relaxed when compared with that of local volunteers, which caused some tensions.

I think most locals are Dutch, and they are much more focused on planning according to their agenda or a schedule....And they [newcomers] say, 'I will do it', but they do it in their own time. So often it is a bit last minute. So, they are a bit less, well, how should I say? Well, more loose, I guess. They do it, but not in the agreed upon way. Sometimes it's a bit difficult, you know, to always have to check whether something has been done. (Interviewee 9, female, Dutch-Italian, core team member, translated from Dutch)

The differences in volunteering styles affect the dynamics and interactions between different groups within the initiative and pose challenges regarding how this diversity should be dealt with. In general, the initiator sees cultural diversity as enrichment and wants to give newcomers the opportunity to 'put their stamp on society'. However, we found that this vision could be undermined in daily realities. The initiative must report to its funders and wants to maintain its good reputation among professionals, the media and expert groups that regularly visit the initiative or attend public events. This requires that the services and events of the initiative work well and have a certain quality. Moreover, since mostly local volunteers handle the coordination, organizational or managerial tasks, they are in a more dominant position within the initiative. Many of them said in informal conversations and interviews that, even though they would like to delegate responsibilities to newcomers, they find it difficult because they do not know whether the tasks will be done on time or in the expected manner.

On the one hand, I get angry at myself because I said I want to trust someone, but I know that I will do his or her job in the end. So, on the one hand, I feel guilty about it. And on the other hand, I am someone who, well, wants things to be done. How do you say that? That I want to see that something is done. (Interviewee 9, female, Dutch-Italian, core team member, translated from Dutch)
This leads to situations in which people in charge are frustrated by newcomers' ways of working. Many locals wish newcomers would take on responsibilities more seriously than they often do.

Participant observation on 28 March 2017: X said that 'the boys' have to bring in their own plates and chairs. $X$ wants them to learn these things. Also, $Y$ was upset because the fridge was 'a mess' and filled with food without name and date tags. Later, they were talking about how A [newcomer] should have done the groceries, but had not done so yet. A few hours later, A did the groceries, but this was too last minute in the eyes of $X$ and $Y$. $X$ and $Y$ were also waiting for $B$ [newcomer], who was apparently supposed to bring them the money for the groceries. No one knew where $B$ was, so they started to become annoyed, since this was not the first time, according to them.

Our research showed that locals wanted to give newcomers space to work in their own manners. However, given that locals hold the leadership positions and, in these positions, have to live up to the standards of other Dutch stakeholders, newcomers would eventually have to learn the 'Dutch way of organizing'. Accordingly, the Dutch way prevails as the standard that newcomers have to adjust to. In the end, newcomers' adapting also contributes to the initiative's goal of working together on integration and can therefore be justified.

Many things work via email and, for example, by scheduling and scripting. And he [newcomer] is also learning, and so I said at one point, I cannot always send you documents through WhatsApp, so you have to check your email....Because here, in the end, many things work via email. (Interviewee 9, female, DutchItalian, core team member, translated from Dutch)

Everyone has an appointment book. And I told them, I think I won't get this appointment book, because I don't like to have appointments every day....And now, I feel I want this appointment book because I have too many appointments. (Interviewee 1, recent male refugee from Syria, volunteer)

As this section has shown, despite the initiative's intention to be inclusive, the dominant position of local volunteers, as well as the initiative's dependence on outside stakeholders and standards, can make it difficult to establish a truly inclusive participatory space in which newcomers can influence the initiative's ways of working.

\subsection{Creating Inclusive Spaces}

Notwithstanding the various challenges encountered in establishing inclusive participatory spaces, there were some occasions in which connections were made through improved communication and experiments. For 
example, during the period in which we conducted our fieldwork, the core team introduced a 'platform': monthly meetings in which the community could evaluate the existing program and suggest new ideas. In one of those meetings, two newcomers introduced the idea of setting up computer lessons themselves (participatory observation, 14 April 2017). If, through such experiments, the number of actively involved newcomers slowly increases, this might also lead to a shift in power relations and practices. Due to this study's limited timeframe, the possibility of such progress could not be explored.

However, one possible outcome of newcomers' increased active participation could be observed during a public event where, compared to other public events, many newcomers helped the kitchen team. As usual, different roles were allocated, and a schedule made by a local volunteer was communicated to the team before the event. However, due to the high number of guests, the assigned roles and the schedule were eventually abandoned. Members of the kitchen team started doing the tasks in front of them, thereby moving back and forth between their own and other peoples' tasks. This led to a somewhat chaotic but nonetheless organic way of working. What struck the team was that this way of working turned out to be quite effective. As opposed to earlier events, when the kitchen team cleaned until 2 am, this team was already finished by $10 \mathrm{pm}$ (participatory observation, 5 May 2017).

A similar way of stepping back from taken-forgranted standards while creating new ones was observed during several public events when people started dancing. People with different backgrounds who did not share a common language could still dance together, and there was never one dominant dance style. This allowed people to learn and mix each other's dance styles, eventually developing new hybrid styles of dancing (participant observation, 8 April 2017).

Finally, the benefits of role switching were observed in the initiative's theatre project, which consisted of actors with Dutch, immigrant or refugee backgrounds. During improvisational rehearsals, actors would randomly switch between the roles of 'guards' and 'people trying to pass the guards', which naturally led to temporary shifts in power relations. The group discussed their feelings afterwards and compared these exercises with reallife experiences, thereby trying to develop a script that did justice to such situations. Since many of the actors with refugee backgrounds had gone through an experience of wanting to get past guards, their input and feelings were of great importance to the development of the script (participant observation, 23 May 2017).

While these examples do not directly inform us about how to establish inclusive participatory spaces for refugees, they shed light on conditions that facilitate a (temporary) abandonment of taken-for-granted positions and standards that might create openings for a shift in power relations and new standards. This will be discussed further in the next section.

\section{Discussion and Conclusion}

In this study, we have explored challenges and opportunities for active participation and inclusion of refugees in community initiatives, considering the context of normalizing exclusive discourses and increasingly neoliberal policies on refugee reception. Our qualitative data, collected in a community initiative in Amsterdam East, has shown that, while there is some room for newcomers to actively participate, there are challenges that inhibit their participation. Moreover, different perceptions on volunteering, the dominant position of local volunteers and influences from external stakeholders make it difficult to establish truly inclusive participatory spaces.

The values and benefits associated with voluntary engagement seemed to diverge between different actors in the initiative. From the initiator's perspective, active participation gives refugees a chance to actively shape their own integration process. Our research showed, however, that refugees' first priority was to start their new lives as soon as possible, which for them meant regaining diplomas and finding paid jobs. Given that volunteer positions seemed to have low status in their home countries and, more importantly, that most volunteer positions in the initiative did not match their backgrounds, newcomers in this study attributed only limited benefits to active participation, which also meant that they did not necessarily see active participation as a way to work on their integration and improve their employability. Another recent study in the Netherlands has also found that newcomers attribute ambiguous images and low priority to volunteering (Bakker et al., 2018). Thus, regarding the first part of our research question (i.e., the challenges and opportunities for participation), we found that there is some space for newcomers to become active in community initiatives, but this space might not necessarily match newcomers' needs, expectations and priorities.

Active engagement in community initiatives takes a lot of time, skills and resources, which affects people's ability to participate (see also Verba et al., 1995). Given their limited resources and given the lack of benefits and future perspective they attribute to volunteering, only a few newcomers choose to become active in community initiatives. This is especially true when positions that could improve their employability are nonexistent, unavailable or too demanding. A recent report on volunteer work of newcomers in the Netherlands also stresses the importance of customized volunteer positions (Bakker et al., 2018). Notably, previous research has shown that finding paid work through voluntary engagement is a challenge for migrants in the Netherlands (Slootjes \& Kampen, 2017). Without an appropriate match, the recent liberal focus on refugees' activation should be adopted with great caution. The focus on participation should not turn into a standardized approach of passing refugees through voluntary programs that will not benefit their employability or integration. Accordingly, also community initiatives should reflect on 
the ways in which their views on active participation and expectations towards newcomers might be influenced by liberal governance (see also Cruikshank, 1999).

The meanings different actors attribute to voluntary engagement also has implications for the second part of our research question regarding how inclusive these recent emerging participatory spaces are. Our research showed that the different meanings and functions attributed to volunteering go hand in hand with different manners of engagement. Based on perceptions of volunteering developed in their home countries, newcomers saw volunteering as a leisure activity. This clashed with the Dutch way of volunteering, which is more scheduled and organized. We also found that spaces developed by community initiatives are somewhat schizophrenic in that they aim to promote both inclusion and adaption. The goal of integration can diminish participatory space for newcomers and pave the way for locals to take on hierarchically higher positions. Though local volunteers wanted to give newcomers space to work in their own ways, the hectic schedule and pressure from external stakeholders to live up to certain standards led to 'cultural cloning' (Essed, 2002), a preference for local volunteers and their way of working. Thus, through such normalization, the Dutch way of organizing can become the standard that newcomers have to adjust to. Their adjustment can then be legitimized by the goal of integration. As our data showed, confrontation with their new environment can stimulate newcomers to reflect on their habitus, work on their dispositions, and then adjust their habitus accordingly (see also Sayer, 2005). However, this process leaves little room for newcomers' perspectives to shape services, relations and working culture within an initiative, as proposed by Thomas and Ely's (1996) integration-and-learning perspective. Instead of changing the game, newcomers learn how to 'play the game' (Greener, 2002). In fact, it can be said that, based on their habitus (see also Cronin, 1996), both newcomers and locals ultimately reproduce structures of domination within an initiative. Moreover, even if some locals try to work in a reflective manner, it remains difficult to keep refugees from being confronted with exclusive stereotypes by all participants, especially during public events.

Nonetheless, there were moments in which established positions and structures were temporarily altered. Our data suggests that, in a situation of organic chaos, people might step back from their established roles more easily, which creates room for others to step in, thereby unsettling power positions and enabling new relations. The same goes for theatre and dancing, which might make it easier for people to temporarily let go of their taken-for-granted positions, be open to the input of others and together establish new creative ways. Critical diversity scholars stress the role of reflection in creating opportunities to counteract normalizing processes (e.g., Zanoni \& Janssens, 2007). We found, however, that it was not so much rational processes, but passion, emotions, playfulness and organic chaos within created safe spaces (see also Ghorashi \& Ponzoni, 2014; Hill Collins, 1991) that were conducive to temporarily suspending normalizing processes. Given that a community initiative's structure is much more fluid than that of traditional organizations, it might be difficult to stimulate reflection on a collective level. However, when compared with traditional organizations, community initiatives have the advantage of being able to organize activities that allow for micro-emancipation through playfulness to create connections.

However, as our research has shown, these moments of inclusion might not be enough to establish stable inclusive participatory spaces for refugees. Reflection is therefore still crucial to identifying the ways in which external stakeholders, organizational goals, local ways of working, and taken-for-granted assumptions and expectations might diminish inclusive participatory spaces for newcomers. Individuals and communities need to be able to connect their everyday personal realities with larger social and historically embedded structures in order to put their own perspectives in context and understand where their expectations, assumptions and takenfor-granted images stem from. This capacity to shift from one perspective to another is what Wright Mills (1959) calls 'sociological imagination'. Both initiators and sociologists can play an important role in the development of spaces for reflection, and in so doing, create spaces in which a deeper notion of democracy is enacted. However, given community initiatives' embeddedness in and dependence on their environments, governmental institutions and societal organizations need to be included in these reflective spaces as well. Based on this and other research, our research team developed the Refugee Academy at VU Amsterdam-an infrastructure for spaces of reflection with different societal and governmental stakeholders, including the community initiative in this study.

\section{Acknowledgements}

We would like to thank all respondents for sharing their personal stories. We also want to express our gratitude to the initiative BOOST Transvaal, especially the initiator and core-team members, for granting us access and taking their time to reflect with us on the research findings.

\section{Conflict of Interests}

The authors declare no conflict of interests.

\section{References}

Adviescommissie voor Vreemdelingenzaken. (2013). Verloren tijd. Advies over dagbesteding in de opvang voor vreemdelingen. Den Haag: ACVZ.

Alvesson, M., \& Willmott, H. (1992). On the idea of emancipation in management and organization studies. Academy of Management Review, 17(3), 432-484. 
Arnstein, S. (1969). A ladder of citizen participation. Journal of the American Institute of Planners, 35(4), 216-224.

Bakker, L., Bekkers, R., Reitsma, J., Sederel, C., Smets, P., \& Younes, Y. (2018). Vrijwilligerswerk: Stimulans voor tijdige participatie en integratie? Den Haag: Ministerie van Sociale Zaken en Werkgelegenheid.

Bohman, J. (1996). Public deliberation: Pluralism, complexity and democracy. Cambridge: MIT Press.

Bourdieu, P. (1977). Outline of a theory of practice. Cambridge: Cambridge University Press.

Bourdieu, P. (1999). The contradictions of inheritance. In P. Bourdieu, A. Accardo, G. Balazs, S. Beaud, F. Bonvin, E. Bourdieu, ... . J. D. Wacquant (Eds.), Weight of the world: Social suffering in contemporary society (pp. 507-513). Cambridge: Polity Press.

Clarke, C. A., Brown, A. D., \& Hailey, V. H. (2009). Working identities? Antagonistic discursive resources and managerial identity. Human Relations, 62(3), 323-352.

Cornwall, A., \& Gaventa, J. (2000). From users and choosers to makers and shapers: Repositioning participation in social policy. IDS Bulletin, 31(4), 50-62.

Cronin, C. (1996). Bourdieu and Foucault on power and modernity. Philosophy \& Social Criticism, 22(6), 55-85.

Cruikshank, B. (1999). The will to empower: Democratic citizens and other subjects. Ithaca: Cornell University Press.

Dagevos, J., \& Odé, A. (2016). Gemeenten volop aan de slag met integratie statushouders. S\&D, 73(4), 12-19.

Ely, R. J., \& Thomas, D. A. (2001). Cultural diversity at work: The effects of diversity perspectives on work group processes and outcomes. Administrative Science Quarterly, 46(2), 229-273.

Engbersen, G., Dagevos, J., Jennissen, R., Bakker, L., Leerkes, A., Klaver, J., \& Odé, A. (2015). No time to lose: From reception to integration of asylum migrants (WRR-Policy Brief 4). The Hague: WRR.

Essed, P. (2002). Cloning cultural homogeneity while talking diversity: Old wines in new bottles in Dutch work organizations? Transforming Anthropology, 11(1), 2-12.

Fung, A., \& Wright, E. O. (2003). Deepening democracy: Institutional innovation in empowered participatory governance. London: Verso.

Gaventa, J. (2006). Finding the space for change: A power analysis. IDS Bulletin, 37(6), 23-33.

Geuijen, K. (2003). Constraints and constructions of meaning in an asylum seekers residence centre. In W. Van Beek, M. Fumerton, \& W. Pansters (Eds.), Meeting culture: Essays in honour of Arie de Ruijter (pp. 323-337). Maastricht: Shaker.

Ghorashi, H. (2005). Agents of change or passive victims: The impact of welfare states (the case of the Netherlands) on refugees. Journal of Refugee Studies, 18(2), 181-198.

Ghorashi, H. (2014a). Routed connections in late modern times. In U. M. Vieten (Ed.), Revisiting I. M. Young on democracy, inclusion and normalisation (pp. 49-67). Houndmills: Palgrave Pivot.

Ghorashi, H. (2014b). Bringing polyphony one step further: Relational narratives of women from the position of difference. Women's Studies International Forum, 43, 59-66.

Ghorashi, H., \& Ponzoni, E. (2014). Reviving agency: Taking time and making space for rethinking diversity and inclusion. European Journal of Social Work, 17(2), 161-174.

Ghorashi, H., \& Sabelis, I. (2013). Juggling difference and sameness: Rethinking strategies for diversity in organizations. Scandinavian Journal of Management, 29(1), 78-86.

Greener, I. (2002). Agency, social theory and social polity. Critical Social Polity, 22(4), 688-705.

Hardy, C., \& Leiba-O'Sullivan, S. (1998). The power behind empowerment: Implications for research and practice. Human Relations, 51(4), 451-483.

Hill Collins, P. (1991). Black feminist thought: Knowledge, consciousness, and the politics of empowerment. New York: Routledge.

Holdo, M. (2015). Strategies of deliberation: Bourdieu and struggles over legitimate positions. Political studies, 63(5), 1103-1119.

Janssens, M., \& Steyaert, C. (2001). Meerstemmigheid: Organiseren met verschil. Leuven: Universitaire Pers.

Jenkins, R. (1992). Pierre Bourdieu. London: Routledge.

Ponzoni, E., Ghorashi, H., \& van der Raad, S. (2017). Caught between norm and difference: Narratives on refugees' inclusion in organizations. Equality, Diversity and Inclusion: An International Journal, 36(3), 222-237.

Raad voor Maatschappelijke Ontwikkeling. (2013). Terugtreden is Vooruitzien: Maatschappelijke veerkracht in het publieke domein. Den Haag: RMO.

Reinhard, A. N. (2016). Local responses to the European refugee crisis: Volunteering and the critique on humanitarianism. Grafo Working Papers, 5, 81-94.

Ritchie, J., Lewis, J., McNaughton Nicholls, C., \& Ormston, R. (2014). Qualitative research practice: A guide for social science students and researchers (2nd ed.). London: SAGE Publications.

Saunders, M., Lewis, P., \& Thornhill, A. (2009). Research methods for business students (5th ed.). Harlow: Pearson Education Limited.

Sayer, A. (2005). The moral significance of class. Cambridge: University Press.

Slootjes, J., \& Kampen, T. (2017). 'Is my volunteer job not real work?' The experiences of migrant women with finding employment through volunteer work. Voluntas, 28(5), 1900-1921.

Start, R. (2016, July 26). Crisisopvang bleek boost voor integratie. NOS. Retrieved from http://nos.nl/artikel /2119745-crisisopvang-bleek-boost-voor-integratie. html

ten Holder, F. (2012). Kleine stappen van grote betekenis: Een nieuw perspectief op humane opvang van asiel- 
zoekers. Amsterdam: Stichting de Vrolijkheid.

Thomas, D. A., \& Ely, R. J. (1996). Making differences matter: A new paradigm for managing diversity. Harvard Business Review, 74(5), 79-90.

van der Raad, S. (2013). Othering and inclusion of ethnic minority professionals: A study on ethnic diversity discourses, practices and narratives in the Dutch legal workplace. Amsterdam: VU University Press.

Vasta, E. (2007). From ethnic minorities to ethnic majority policy: Multiculturalism and the shift to assimilationism in the Netherlands. Ethnic and Racial Studies, 30(5), 713-740.

\section{About the Authors}

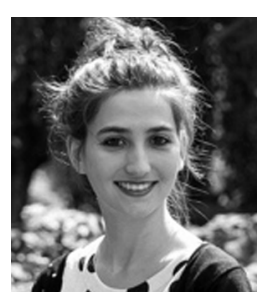

Maria Charlotte Rast (MSc, M Law) obtained the titles Master of Law (summa cum laude) from the University of Bern, Switzerland, in 2014 and Master of Science (cum laude) in Sociology from VU Amsterdam, the Netherlands, in 2017. She currently is a PhD candidate at the Department of Sociology of VU Amsterdam. Her research is affiliated with the Refugee Academy of VU Amsterdam and focuses on the role of engaged scholarship in the development of inclusive spaces for refugees.

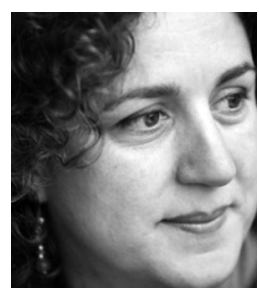

Halleh Ghorashi (PhD) is Professor of Diversity and Integration in the Department Sociology at the Faculty of Social Sciences, VU Amsterdam, the Netherlands. She is the author of Ways to Survive, Battles to Win: Iranian Women Exiles in the Netherlands and the United States (2003) and co-editor of Paradoxes of Cultural Recognition: Perspectives from Northern Europe (together with S. Alghasi and T. H. Eriksen, 2009) and Muslim Diaspora in the West: Negotiating Gender, Home and Belonging (with Haideh Moghissi; 2010). 